\title{
Aspekty ochrany identifikačních štítků motorových vozidel
}

\section{Aspects of Vehicle Identification Labels}

\author{
Petra Kolitschová, Jaroslav Kerbic, Roman Rak* \\ Vysoká škola finanční a správní, Praha, Česká republika
}

\begin{abstract}
Abstrakt
Příspěvek se zabývá problematikou identifikace vozidla, zejména rozmanitými identifikačními štítky (homologačními, datovými, typovými, štítky výbav, sekundárními identifikačními štítky), jejich historii a zabezpečením různými ochrannými prvky (mikrotextem, opticky variabilními prvky $\left(\mathrm{OVP}^{1)}\right)$, prvky viditelnými pouze v ultrafialovém světle apod.) proti jejich padělání či pozměňování.
\end{abstract}

Klíčová slova: identifikace vozidla, identifikační štítek, homologační štítek, ochranné prvky, mikrotext, UV prvky, opticky variabilní prvky.

1) V angličtině OVE - Optical Variable Element(s).

\section{1. ÚVOD}

Spolu s technickým vývojem samotných vozidel dochází i k vývoji v oblasti zabezpečení a ochrany jejich identifikačních znaků. Cílem je zabránit falšování a pozměňování identity vozidla, které je typické pro všechny aktivity spojené se snahou skrýt skutečnou identitu vozidla pocházejícího ze spekulativní nebo trestné činnosti, a to z nejrůznějších důvodů.

Změny ze strany výrobců v identifikačních znacích můžeme zaznamenat jak při ochraně samotného klíčového identifikátoru VIN (Vehicle Identification Number), tak i při ochraně nejrůznějších štítků na vozidle, které v sobě nesou kromě jiných (významných) informací i informace o identitě vozidla nebo informace o technických či administrativních charakteristikách, úzce spojených s konkrétním typem vozidla. Na základě těchto informací je pak možno vozidlo identifikovat, a to druhově (typově) nebo individuálně. Známe-li způsob primární výroby identifikačních markantů (štítků, nálepek, „ražených“ sériových identifikačních čísel apod.), včetně jejich ochranných prvků, můžeme kvalifikovaně vyjadřovat názory o jejich originalitě nebo o př́ípadném padělání či pozměňování.

\begin{abstract}
The paper discusses the problems of vehicle identification, especially the assorted identification labels (homologation, data, type, equipment labels, secondary identification labels), their history and security using various security elements (micro-text, optical variable elements $\left(\mathrm{OVE}^{2}\right)$, elements that are visible only under ultraviolet light, etc.) against forging or alteration.
\end{abstract}

Keywords: Vehicle identification, identification label, homologation label, security elements, micro-text, UV elements, optical variable elements.

2) OVE - Optical Variable Element(s).

\section{HISTORIE A SOUČASNOST}

Technologický způsob provedení identifikačních znaků vozidla se vyvíjel a dále vyvíjí. Způsob provedení (výroby) identifikátorů je především ovlivněn:

- bezpečnostními požadavky na trvanlivost a neměnnost (nezaměnitelnost) identifikačních znaků,

- umístěním na vozidle,

- výrobními technologiemi (včetně ochranných prvků),

- používaným materiálem a jeho vlastnostmi,

- cenou,

- možností automatického zpracování, technologiemi rychlého prověřování originálnosti identifikačních znaků v průběhu rozmanitých kontrol,

- dostupností těchto technologií odborným pracovištím,

- estetičností.

Historicky prvním materiálem použivaným při identifikaci vozidel byl kov, pak papír, umělé hmoty, sklo a v posledním desetiletí také digitální prostředí (identifikační a informační znaky jsou ukládány do elektrotechnických prvků (pamětí), které jsou součástí vozidla). 

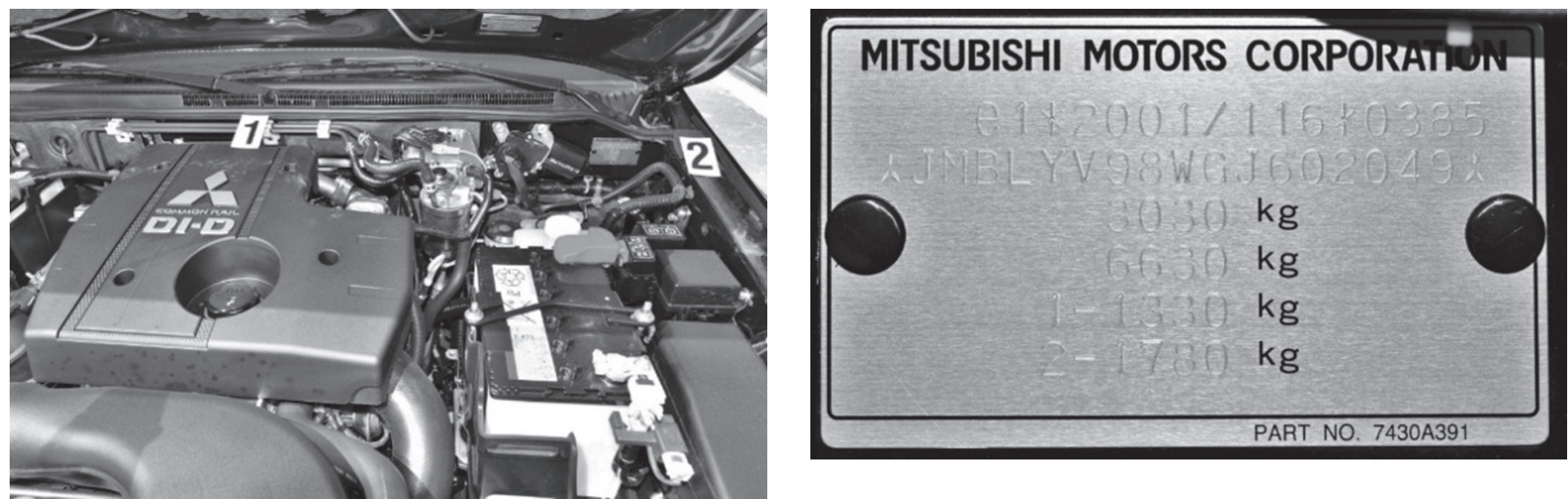

Obr. 1 Ukázka kovového identifikačního štítku (vpravo), nacházejicího se v místě označeném „, 2“ (snímek vlevo) (autor Roman Rak).

Fig. 1 Demonstration of a metallic identification label (on the right side), found at position "2" (image on left side) (author Roman Rak).

\section{Ochranné prvky identifikátorů - VIN na karosérii vozidla}

Identifikační znaky vozidla se v minulosti realizovaly zejména u identifikátoru VIN pomocí ražby či gravírování. Z hlediska zabezpečení identifikátorů VIN zapracovaných přímo do karosérie vozidla se pro jejich zabezpečení proti padělání či pozměňování realizovalo

- technologií výroby,

- fontem (tvarem) písma,

- rozměry písma,

- vzdálenostmi mezi tzv. delimitery (hraničními, oddělovacími znaky) VIN,

- tvarem, podobou delimiterů,

- ochranným lakem,

- ochrannými přelepy,

- skrytými umístěními identifikátorů.

Podle mezinárodních norem musí být VINem označena samonosná karosérie nebo rám vozidla tak, aby se VIN stal její neoddělitelnou částí, VIN se tedy razí nebo gravíruje př́ímo do kovu.

Podle mezinárodních norem musí výrobce umístit před a za VIN oddělující znak, tzv. delimiter. Jeho vzhled, tvar, způsob ražby je sám o sobě ochranným prvkem, ale i rozteč středů mezi těmito delimitery (kde jsou umístěny významové hodnoty - znaky, tedy číslice a písmena) je u většiny výrobců pevně daná, např. $100 \mathrm{~mm}$.

Z hlediska povrchových úprav jsou pak různé přístupy, které mohou padělatelům VINu ztěžovat proces padělání. VIN se může např. gravírovat přes finální povrchovou úpravu (takže je vidět kovový vzhled číslic a písmen v plechu), nebo naopak po vyražení či gravírování přestříkávat různými vrstvami laku, včetně např. i poslední vrstvy průhledného, ochranného laku, jež chrání metalické barvy. Toto záleží na výrobci. V mnoha případech (obvykle německé automobilky) přes VIN lepí transparentní fólii, jež chrání VIN před korozí, ale zároveň má vlastnost ochranného prvku proti padělání či napodobování.

VINem mohou být označovány různé díly karosérie i komponenty vozidla, některé z nich mohou mít charakter utajení místa jejich umístění před laickou veřejností.

\section{OCHRANNÉ PRVKY IDENTIFIKÁTORŮ - KOVOVÉ ŠTÍTKY}

U homologačních a datových (typových) štítků se používala v minulosti technologie kovových štítků (obvykle hliníkových), umístěných v motorovém prostoru a přichycených pomocí nýtů, které mohly mít základní ochranný prvek - neobvyklé provedení hlavy nýtu ozdobným způsobem, obsahujícím např. název výrobce, logo apod.

Díky neestetickému vzhledu kovových štítků i jejich způsobu uchycení k vozidlu se tyto umist'ovaly obvykle do motorového prostoru. Samy o sobě neměly žádné ochranné prvky a byly lehce padělatelné, resp. existuje velké množství soukromých firem, které za úplatu dokáží vyrobit štítek jakéhokoli výrobce pro jakýkoliv model vozidla.

V současné době se kovové identifikační štítky použivají už jen minimálně u některých japonských značek (např. Mitsubishi). Byly vystřídány samolepícími nálepkami.

\section{VÝHODY SAMOLEPÍCÍCH IDENTIFIKAČNÍCH NÁLEPEK}

Identifikační (informační) nálepky, vyhotovené v samolepícím provedení, mají oproti kovovým štítkům řadu výhod:

- jsou tenčí,

- jsou lehčí,

- jsou levnější,

- lze je vyrábět $\mathrm{v}$ různých tvarech a $\mathrm{v}$ různém barevném provedení,

- jsou estetičtější,

- lze je umístit kamkoliv,

- lze je umístit na vozidlo ve velkém počtu,

- lépe se ukrývají,

- ve stejném materiálovém zpracování (včetně ochranných znaků) lze vyrobit více různých druhů identifikátorů pro jeden typ vozidla,

- nálepky lze vyrábět i s využitím samodestruktivních technologií, zabraňujících nálepku sejmout a přenést na jiné vozidlo, 
- nálepku lze vyrobit s různými ochrannými prvky, zabraňujícími její pozměňování či padělání.

Moderní homologační, typové, datové nebo informační štítky na vozidlech v podobě samolepicích nálepek lze vyrábět s různými ochrannými prvky ve velmi vysoké kvalitě, zabraňující jejich padělání či pozměňování.

Obecně platí, čím je vozidlo dražší, tj. vyšší třídy, tedy vyráběné i v menších sériích než vozy střední a nižší třídy, tím je věnována i vyšší pozornost jeho ochraně před různými formami automobilové kriminality. Identifikační štítky pak obsahují více ochranných prvků. Z hlediska výrobních nákladů jsou tyto štítky pak pochopitelně ale i nepatrně dražší.

Různí výrobci zabezpečují identifikační štítky různými ochrannými prvky, využívajícími různé technologie či principy ochrany. U vozidel nižších trríd, vyráběných ve velkých sériích $\mathrm{z}$ důvodu potřeby nižších nákladů, mohou být z pohledu výrobce vozidla nižší požadavky na zabezpečení ochrany identifikačních štítků. Jaká ochrana proti padělání či pozměňování různých identifikačních štítků bude použita pak výhradně záleží na politice a prioritách výrobce daného typu vozidla.

\section{OCHRANNÉ PRVKY SAMOLEPICÍCH IDENTIFIKÁTORŮ VOZIDEL}

Z pohledu tvorby a zajištění ochranných prvků a přístupů $\mathrm{k}$ identifikačním štítkům pak můžeme tyto členit na:

- samodestrukční nálepky,

- opticky variabilní prvky (OVP),

- mikrotexty,

- UV ochranné prvky,

- ochranné transparentní přelepové fólie,

- logické, informační vazby.

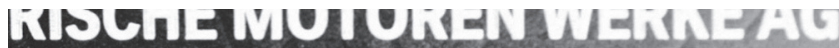
$107 / 46 * 1682$ WYS310003B60147

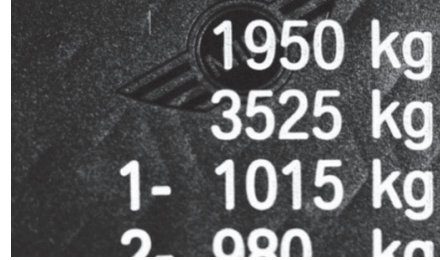

Obr. 2 V pravé části snímku vidíme samodestrukčni linie, ve kterých se homologační štítek trhá při pokusu o jeho přenesení na jiné vozidlo (autor Roman Rak).

Fig. 2 In the right side section of the image, we see the selfdestructive lines along which the homologation label tears upon attempt to transfer it to another vehicle (author Roman Rak).

\subsection{Samodestrukční nálepky}

Identifikační, typový či informační štítek je vyroben tak, aby byl odolný proti působení sil, které vznikají při běžném provozu a údržbě vozidla, jako je např. mytí apod. Zároveň je navržen tak, aby jej nebylo možno zneužít na jiném vozidle. V praxi to znamená, že štítek (v podobě nálepky) je samodestruktivní a při pokusu přenést jej na jiné místo (zpravidla na jiné vozidlo) se trhá, deformuje, takže se sám působením sil člověka zničí (potrhá). Na nepoškozeném identifikačním štítku (obvykle dnes $\mathrm{v}$ podobě nálepky) lze při bočním osvětlení velmi často pozorovat struktury v podobě šestistěnů (připomínající medové plástve) nebo vlnek. Podél těchto křivek pak dochází k odtrhávání jednotlivých částí identifikátorů. Zároveň po obvodu štítku (nálepky) můžeme vidět nastřižené kraje, které rovněž fungují jako počátky samodestruktivních linií.

\subsection{Opticky variabilní prvky $\left(\mathrm{OVP}^{3)}\right)$}

Opticky variabilní prvky jsou obecně ochranné obrazce, loga výrobců, nebo na první pohled zcela neviditelné texty, které lze spatřit jen pod určitým úhlem dopadajícího světla na identifikační nálepku v místech výskytu opticky variabilních prvků. Opticky variabilní prvky mají různé velikosti a mohou být kombinovány s mikrotexty, umístěnými do jednotlivých obrazců OVP (do loga výrobce, textového názvu výrobce apod.).

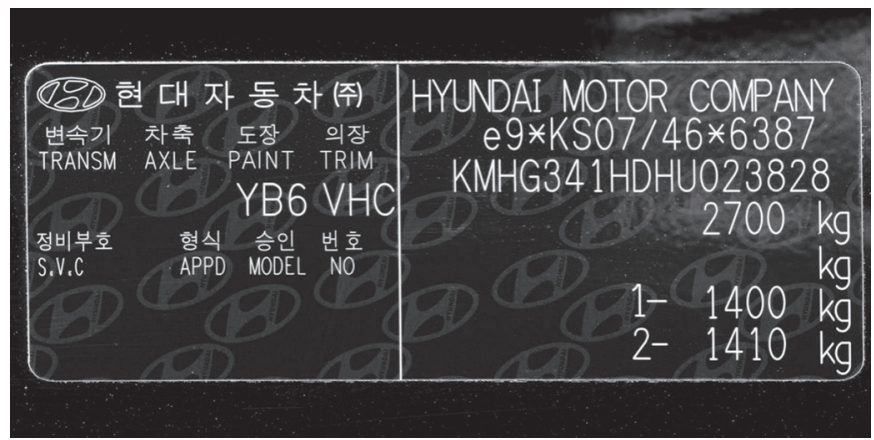

Obr. 3 Ukázka opticky variabilního prvku - logo Hyundai, které je viditelné jen pod určitým úhlem dopadajícího světla. V logu (pravá nožička písmena H) je zároveň použit ochranný prvek ,,mikrotext“, ve kterém je napsáno slovo „Hyundai“" (autor Roman Rak).

Fig. 3 Demonstration of an optical variable element - Hyundai logo, which is visible only under a certain light angle. In the logo (right leg of the letter $H$ ), an additional "micro-text" element is also used, which contains the word "Hyundai" (author Roman Rak).

\subsection{Mikrotexty}

Mikrotexty jsou vyhotoveny velmi malým písmem na hranici čitelnosti. Jsou ostře tištěné a ještě dobře čitelné. Na druhé straně je mikrotext vyhotoven takovým způsobem, že jej není triviální kopírovat (aniž by se text znehodnotil - napřr. slil či rozmazal) nebo tisknout méně kvalitními tiskovými technikami. Mikrotext bývá umístěn jako podkladový text identifikační nálepky, po obvodech nálepky nebo je umist'ován do obrazců různých prvků - do loga výrobce, do jeho názvu apod.

\subsection{UV ochranné prvky}

Skryté ochranné prvky, viditelné v ultrafialovém světle (UV) se začaly používat přibližně před deseti lety. Při prověřování vozidel, přejíždějících nyní už jen pomyslné vnitřní hranice jednotlivých zemí EU, je používají zejména složky cizinecké policie, které především kontrolují cestovní doklady osádek vozidel. Pro ověřování pravosti dokladů se používají i UV lampy, není pak již

\footnotetext{
OVE - Optical Variable Element(s).
} 


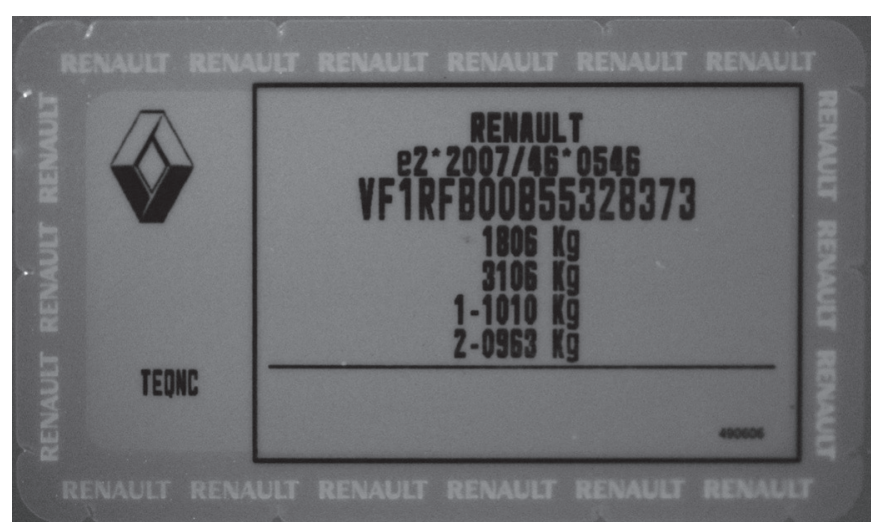

Obr. 4 Ukázka ochranného transparentniho přelepu přes bilý homologačni štitek. Po okrajich transparentni fólie je v UV světle patrný nápis RENAULT po celém obvodu nálepky. Zároveň můžeme spatřit trojúhelnikové „nářezy“, jež zpưsobuji destrukci štítku $v$ mistě jejich výskytu při pokusu přenést štitek na jiné vozidlo (autor Roman Rak).

Fig. 4 Demonstration of protective transparent cover foil over the white homologation label. Under UV light, the inscription RENAULT is visible around the full perimeter of the label at the edges of transparent foil. At the same time, we can see triangular "cuts", which trigger the destruction of the label at its contact point upon attempt to transfer the label to another vehicle (author Roman Rak).

složité zkontrolovat současně i pravost/originálnost identifikačních štítků a tím kontrolu rozšírit i na vozidlo.

UV ochranné prvky jsou zhotovovány pro zobrazení UV světlem o vlnové délce $365 \mathrm{~nm}$. Ochranné prvky jsou různorodé, v závislosti na požadavcích a zvycích výrobce. V UV světle se obvykle realizují tyto grafické či textové prvky:

- obvodové linie štítků,

- texty uvnitř štítků, nesoucí informace o vozidle (štítek je celý čitelný v denním bílém i UV světle),

- názvy výrobce,

- logo výrobce,

- optické variabilní prvky (OVP) jsou zároveň čitelné i v UV světle,

- různé tečky, čárky, speciální znaky, které na první pohled vypadají jako tiskové chyby, jako šum při výrobě nálepky.

UV ochranné prvky jsou typické pro francouzské, německé a japonské výrobce, zejména pak u dražších, luxusnějších vozidel střední a vyšší třídy.

Francouzští výrobci s oblibou používají transparentní fólie, které jsou přelepovány přes homologační štítky. Tento př́istup má dva důvody: transparentní přelep chrání homologační štítek akto se to jeví na první pohled. Ve skutečnosti v obvodové části, která nezasahuje opticky do homologačního štítku, nalezneme ochranné UV prvky.

U koncernu TPCA (Toyota Peugeot Citroën Automobile) to jsou pak loga, názvy továrních značek, nebo texty („TPCA“,,SN“ apod.). Zajímavé je, že u některých modelů to je logo/název jednoho výrobce, u jiných zase loga/názvy dvou výrobců, jež jsou uváděny společně. Tento postup je závislý na tom, v jakém výrobním závodě je vozidlo vyráběno nebo zda se daný model prodává pod různými obchodními názvy (dvou či více továrních značek - Peugeot,
Citroen, DSA). Může se totiž jednat o technicky stejný typ vozidla, ale nesoucí jiné obchodní označení (např. dvojice modelů značky Peugeot Boxer-Citroen Jumper).

Podobně nás nesmí překvapit ani UV ochranný text „Nissan“ na nálepce vozidla Renault, protože se primárně jedná o model/ typ vozidla, konstrukčně navržený Nissanem pro jeho vozidla a následně vyráběný pod tovární značkou Renault (i pod jiným obchodním názvem), nebo o vozidlo Renault, vyráběné ve výrobním závodu Nissanu. V posledních letech se poměrně často setkáváme s různými formami spolupráce různých továrních značek v globálním prostředí za účelem přežití. Vznikají tak různá uskupení výrobců, koncerny apod., což se projevuje i do identifikace vozidel v podobě přenášených standardů, zvyklostí apod.

\subsection{Ochranné transparentní přelepové fólie}

Ochranné, transparentní fólie mají obecně dvojí využití.

Primárně chrání identifikátor (VIN, homologační štítek) vozidla před průnikem vody, korozí, fyzickým či chemickým poškozením, znečištěním apod. Tyto průhledné přelepy jsou vyrobeny tak, aby plnily i ochrannou funkci proti padělání či pozměňování samotného identifikátoru. Mohou být vyrobeny v samodestruktivním provedení, či z průhledného materiálu, který se špatně napodobuje jeho vlastnostmi, tvarem (obvodovými křivkami, zaoblením hran, tloušt'kou, přilnavostí apod.).

Transparentní ochranné přelepy obsahují u některých továrních značek (zejména francouzských a německých výrobců) skryté obrazce, linie či texty, viditelné pouze v UV spektru (zpravidla o vlnové délce $365 \mathrm{~nm}$, jež je standardně používána $\mathrm{v}$ lampách pro kontrolu dokladů a bankovek/cenin).

Většina transparentních přelepů časem ztrácí své plastické a optické vlastnosti, tvrdnou, stávají se křehkými, mohou žloutnout, podobně jako fotografie, zpracovávané klasickou mokrou cestou. Pokud víme (máme referenční databázi), že identifikátor má mít přelep a ochranné prvky, a něco z tohoto absentuje, máme jasný signál, že se s identifikací vozidla nějak manipulovalo.

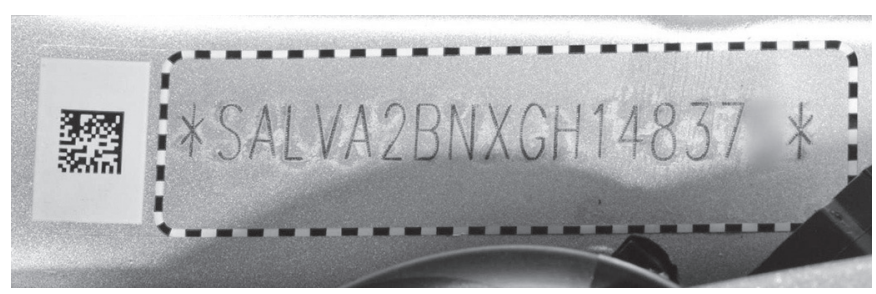

Obr. 5 Ukázka ochranného transparentního přelepu vyraženého identifikátoru VIN u vozidla Range Rover (autor Roman Rak).

Fig. 5 Demonstration of the protective transparent cover foil of a stamped VIN identifier of a Range Rover vehicle (author Roman Rak).

Transparentní fólie, přelepované přes identifikační (zejména homologační) štítky, kromě ochranné funkce před mechanickým poškozením a ochranné funkce pomocí UV prvků obsahují i možnost ochrany štítku před jeho neoprávněným přenesením na jiné vozidlo. Ochranná, transparentní přelepová fólie je pak samodestruktivní. Můžeme to poznat podle toho, že po obvodu ochranné transparentní fólie jsou trojúhelníkové výřrzy. V těchto místech se pak fólie při pokusu o sejmutí trhá a ničí. 


\subsection{Logické a informační znaky}

Na homologačních, identifikačních, datových a typových štítcích motorových vozidel můžeme nalézt velké množství rozmanitých kódů (alfanumerických sekvencí), které jsou informačně vztaženy ke konkrétním charakteristikám vyrobeného vozidla (jeho barvě, typu či výkonu motoru, převodovky, provedení, k jednotlivým komponentům jeho výbavy - dvouzónové klimatizace, audiosystému, homologovanému typu apod.). Jestliže tyto identifikační znaky neoprávněně a bezmyšlenkovitě pachatel měnící identitu vozidla přenese na vozidlo jiné, poruší logickou harmonii mezi charakteristikami vozidla a charakteristikami na štítcích, které by měly odpovídat skutečnému stavu vozidla. $\mathrm{Na}$ základě znalosti obsahu a způsobu provedení identifikačních štítků pak můžeme neoprávněnou manipulaci odhalit.

\section{ZÁVĚR}

Abychom účinně dokázali rozpoznávat padělané či pozměněné identifikátory, homologační či typové nebo datové štítky, měli bychom mít k dispozici referenční databázi originálních vzorů. Při systematické kontrole pak vycházíme z výše uvedeného poznatkového fondu, znalostí typických př́stupů jednotlivých výrobců vozidel a našich minulých praktických činností. Př́istupy výrobců $\mathrm{k}$ identifikaci vozidla, technologie, materiály apod. se dnes obvykle mění v časové periodě 3-5 let, a pak jsou zpravidla shodné, typické pro vozidla konkrétní třídy - např. homologační štítek, typový a datový štítek, VIN pod sklem - jsou vyráběny ze shodného předtištěného materiálu apod.

\section{LITERATURA}

[1] MATOUŠKOVÁ, I., MORAVČÍK, L', RAK, R. a kol. e Call - Inteligentný dopravný systém (aspekty právne, technické, informačné a psychologické). Bratislava: MAGNET PRESS, SLOVAKIA s. r. o., 2015, 688 s. ISBN 978-80-89169-31-3, EAN 9788089169313.

[2] MORAVČÍKOVÁ, J. Cross-Border Exchange of Information about Traffic Offences through EUCARIS. In: Automotive safety 2016: proceedings of the X International Science-Technical Conference: 22-24 February 2016. Kielce University of Technology, Kielce, 2016, s. 227-234. ISBN 978-83-63792-70-1.

[3] MORAVČÍK, L. Automobilová kriminalita na Slovensku a problémy pri jej riešení. In: Zbornik z 13. medzinárodného sympózia konaného dña 8. 9. 2016 v rámci medzinárodného veltrhu SECURITY BRATISLAVA 2016. Akadémia Policajného zboru v Bratislave, Bratislava, 2016, s. 128-140. ISBN 978-80-8054-691-5, EAN 9788080546915.

[4] MORAVČÍK, L., JAŚKIEWICZ, M. Integrated Intelligent Safety Systems, In: Perner's Contacts - Electronical technical journal of technology, engineering and logistic in transport. No 2/2016, s. 55-73. ISSN 1801-674X.

[5] MORAVČÍK, L'., JAŚKIEWICZ, M. Safe and Intelligent Vehicle Systems. In: Automotive safety 2016: proceedings of the $X$ International Science-Technical Conference: 22-24 February 2016. Kielce University of Technology, Kielce, 2016, s. 217-226. ISBN 978-83-63792-70-1.

[6] TUREČEK, J. et al. Police technique. Aleš Čeněk, Praha, 2008, 316 s. ISBN 978-80-7380-119-9.

[7] TUREČEK, J. Rentgens. Security Magazin. 4(1997), s. 17-19. ISSN 1210-8723.

\section{Správná citace:}

KOLITSCHOVÁ, P., KERBIC, J., RAK, R. Aspekty ochrany identifikačních štítků motorových vozidel. Soudní inženýrství, 2018, 29(3), 2-6. ISSN 1211-443X. 